\title{
Glycohistochemistry of the External Nasal Gland of Two Lizards (Podarcis sicula campestris and Chalcides chalcides)
}

\author{
Domenico Ferri and Giuseppa Esterina Liquori \\ Department of Zoology, University of Bari, Via E. Orabona, 4, I-70125 Bari, Italy.
}

Received for publication October 25, 1996 and in revised form March 14, 1997

\begin{abstract}
Secretory cell glycoconjugates of the external nasal glands of ruin lizard and seps were investigated by prelectin staining methods (periodic acid-Schiff, alcian blue, high iron diamine) and lectin histochemistry in combination with neuraminidase digestion. Five plant lectins ICanavalia ensiformis, Triticum vulgare, Glycine max, Lotus tetragonolobus and Arachys hypogaea) conjugated with

horseradish peroxidase were tested. Two different secretory cell types could be distinguished in the glandular tubules in both species examined. Lectin histochemistry revealed a microheterogeneity of mucins produced by the different secretory cell types of the two lizards regarding to the distribution pattern of glycosidic residues in glycoproteins.
\end{abstract}

Key words: Glycoconjugates, Lectins, External nasal gland, Lacertidae, Scincidae

\section{Introduction}

The external nasal gland of reptiles has long been studied histologically and extensive reviews have been recorded by Parsons (1970) [18] and Dunson (1976) [4].

It is known that the external nasal gland contributes to the production of the nasal mucus that appears to play an important role in a number of functions, such as chemoreception and microbial defense.

In certain species, this gland has been shown to be capable of elaborating a hyperosmotic saline solution and therefore to represent an important means for the excretion of electrolytes [23].

Most of the previous studies on the lacertilian external nasal gland have aimed at its physiology and, in particular, its role in the excretion of electrolytes [schmidt]. Thus, little is known as to the histochemistry of the mucussecreting cells of this gland, which has been studied merely using pre-lectin histochemical staining methods, in a few reptile species $[7,8,20,22]$.

Oligosaccharides appears to play a crucial role in the structure and functions of glycoconjugates in many biological events $[3,12,16,27]$.

Since also a variety of properties of nasal mucus depend upon its carbohydrate components, in the present work a histochemical study has been made to determine the nature and distribution pattern of saccharide residues

Correspondence to: Prof. Domenico Ferri, Department of Zoology, University of Bari, Via E. Orabona, 4 I-70125 Bari, Italy. in secretory glycoproteins elaborated by the nasal gland of two lizards: Podarcis sicula campestris (Lacertidae), and Chalcides chalcides (Scincidae). In addition to traditional staining methods (periodic acid-Schiff, alcian blue, high iron diamine), that provide a basis for histochemical classification of mucosubstances $[25,26]$, five plant lectins conjugated with horseradish peroxidase were employed to analyze the carbohydrates.

\section{Materials and Methods}

Adult male and female ruin lizards (Podarcis sicula campestris), and seps (Chalcides chalcides) were collected from areas around Bari (Italy). The animals were sacrified with ether and their nasal conchae were quickly removed.

The samples were fixed in $10 \%$ formalin, dehydrated in graded ethanol series, and embedded in paraffin wax.

Certain tissue samples were fixed in $4 \%$ glutaraldehyde in $0.1 \mathrm{M}$ phosphate-buffered saline (PBS) at $\mathrm{pH} 7.4$ for $4 \mathrm{hr}$ at $20^{\circ} \mathrm{C}$. After an overnight buffer wash at $4^{\circ} \mathrm{C}$, specimens were postfixed in $1 \%$ osmium tetroxide in PBS for $1 \mathrm{hr}$ at $20^{\circ} \mathrm{C}$., dehydrated in alcohol, and embedded in Araldite (Merks; Darmstadt, Germany).

For the histochemistry of mucosubstances, serial paraffin sections were cut at $5 \mu \mathrm{m}$, mounted, deparaffinized, hydrated and stained by means of the following traditional histochemical methods:

1. Alcian blue (pH 2.5)-periodic acid Schiff (ABPAS) to distinguish acidic from neutral glycoconjugates [17]. 
2. Alcian blue ( $\mathrm{AB})$ at $\mathrm{pH} 1.0$ and $\mathrm{AB} \mathrm{pH} 2.5$ [11], and

3. High iron-diamine-Alcian blue (HID-AB) for differentiating sialomucins from sulfomucins [24].

4. Alcian blue (AB) $\mathrm{pH} 2.5$ following testicular hyaluronidase (Sigma, St. Louis, USA) digestion for characterization of glycosaminoglycans [2].

Semithin sections of samples embedded on Araldite were stained with the PAS [13] and silver methods [1] to identify vicinal diols of carbohydrates.

Binding with 5 plant lectins conjugated with horseradish peroxidase was tested as well to determine the nature and distribution pattern of saccharide residues in the secretory cells of the nasal glands. The 5 lectins employed and their sugar specificities [10] are illustrated in Table 1. PNA and SBA were tested with and without pretreatment with sialidase (Neuraminidase type $\mathrm{V}$ from Clostridium perfrigens, Sigma, St. Louis, USA).

Binding with peroxidase labeled lectins was performed as reported previously [6]. Briefly, hydrated sections were exposed to $3 \%$ aqueous hydrogen peroxide for 10 min to inhibit the activity of endogenous peroxidase and then incubated with peroxidase labeled lectins for $30 \mathrm{~min}$ at room temperature. The activity of the horseradish peroxidase was then visualized histochemically with 3-3'-diaminobenzidine (DAB)-hydrogen peroxidase $\left(\mathrm{H}_{2} \mathrm{O}_{2}\right)$ medium [11]. Finally, stained sections were dehydrated in graded ethanols, cleaned in xilene, and mounted with DPX. The control tests for the lectin stainings included: a) substitution of each peroxidase labeled lectin with PBS, b) incubation in peroxidase labeled lectin in the presence of the appropriate competing sugar (Table 1), to substantiate the specificity of lectin bindings, and c) incubation of untreated sections with $\mathrm{DAB}-\mathrm{H}_{2} \mathrm{O}_{2}$ to check the activity of endogenous peroxidase.

Digestion with sialidase was performed by overlaying hydrated sections for $30 \mathrm{~min}$ at $37^{\circ} \mathrm{C}$, in a humid Petri dish, with a drop of a solution of acetate buffer $0.05 \mathrm{~mol} / \mathrm{l}$ (pH 5.5), containing sialidase $1 \mathrm{U} / 10 \mathrm{ml}$ and $0.1 \%$ calcium chloride [14] prior to treatment with $\mathrm{H}_{2} \mathrm{O}_{2}$ as described above. Control sections were incubated in acetate buffer without the enzyme.

\section{Results}

\section{a) Podarcis sicula campestris}

The external nasal gland of Podarcis sicula campestris was of a ramified tubular type. The duct of the gland entered the vestibulum, close the anterior end of the cavum nasi proprium.

Two well differentiated tracts could be distinguished in the glandular tubules: a proximal tract, consisting of striated cells, without any apparent secretory granules, and a distal (blind) tract, composed of two different secretory cell types.

The first cell type (C1) included numerous large cells containing a basal nucleus. Their secretory product was PAS negative (Fig. 1A), and lacked affinity towards AB or HID. These cells failed to bind any peroxidase lectin conjugates tested.

The second cell type (C2) included small cells which were compressed among the first type and provided a secretory product revealing a strong PAS reaction (Fig. 1A) and intense alcianophilia at $\mathrm{pH} 1.0$ and $\mathrm{pH} 2.5$, resistant to hyaluronidase pretreatment. The second cell type stained purple-blue with the AB-PAS sequence and allowed an evident affinity towards HID. No binding was seen with WPA, Con A or PNA. Digestion with sialidase imparted weak reactivity with this latter lectin (Fig. 1B). The secretory granules reacted intensely with SBA (Fig. 1C) and exhibited affinity towards WGA (Fig. 1D). Digestion with sialidase did not affect the affinity towards SBA.

The striated cells did not react with PAS, AB or HID staining procedure. In these cells no binding sites were detected with any of the lectins tested.

\section{b) Chalcides chalcides}

Three different segments could be distinguished in the glandular tubules of the external nasal gland of the seps: the distal (blind), intermediate and proximal tracts.

The distal tract was composed of two different secretory cell types (Fig. 2A). The first cell type (C1), included large numerous cells; some of these exhibited a moderate PAS reaction, a weack alcianophilia at $\mathrm{pH} 1.0$

Table 1. Characteristics of the plant lectins utilized

\begin{tabular}{|c|c|c|c|c|c|}
\hline Lectin & Source & $\begin{array}{l}\text { Binding } \\
\text { specificity }\end{array}$ & $\begin{array}{c}\text { Lectin } \\
\text { concentration } \\
(\mathrm{mg} / \mathrm{ml})\end{array}$ & $\begin{array}{c}\text { Inhibito } \\
\text { sugar }\end{array}$ & \\
\hline Con A & Canavalia ensiformis & $\begin{array}{l}\text { D-mannose } \\
\text { D-Glucose }\end{array}$ & 0.05 & $0,1 \mathrm{M}$ & $\mathbf{M} \alpha \mathbf{M}$ \\
\hline WGA & Triticum vulgaris & $($ GlcNAc $\beta 1,4) n$ & 0.02 & $0,01 \mathrm{M}$ & TACT \\
\hline SBA & Glycine max & GalNAc & 0.02 & $0,2 \mathrm{M}$ & GalNAc \\
\hline PNA & Arachys hypogaea & Gal $\beta 1$, 3GalNAc & 0.06 & $0,2 \mathrm{M}$ & Gal \\
\hline WPA & Lotus tetragonolobus & $\begin{array}{l}\text { L-Fuc } \alpha 1,6 \mathrm{GlcNAc} \text { and } \\
\text { L-Fuc } \alpha 1,2 \mathrm{Gal} \beta 1,4[\mathrm{~L}-\mathrm{Fuc1}, 3] \\
\text { GlcNAc } \beta 1,6 \mathrm{R}\end{array}$ & 0.10 & $0,2 \mathrm{M}$ & L-fuc \\
\hline
\end{tabular}

Gal: galactose, GalNAc: N-acetylgalactosamine, GlcNAc: N-acetylglucosamine, L-Fuc: L-fucose, M $\alpha \mathbf{M}$ : methyl- $\alpha$-mannopyranoside, TACT: $\mathbf{N}, \mathbf{N}^{\prime}, \mathbf{N}^{\prime \prime}$-triacetylchitotriose, $\mathrm{R}$ : remainder of oligosaccharide residues. 

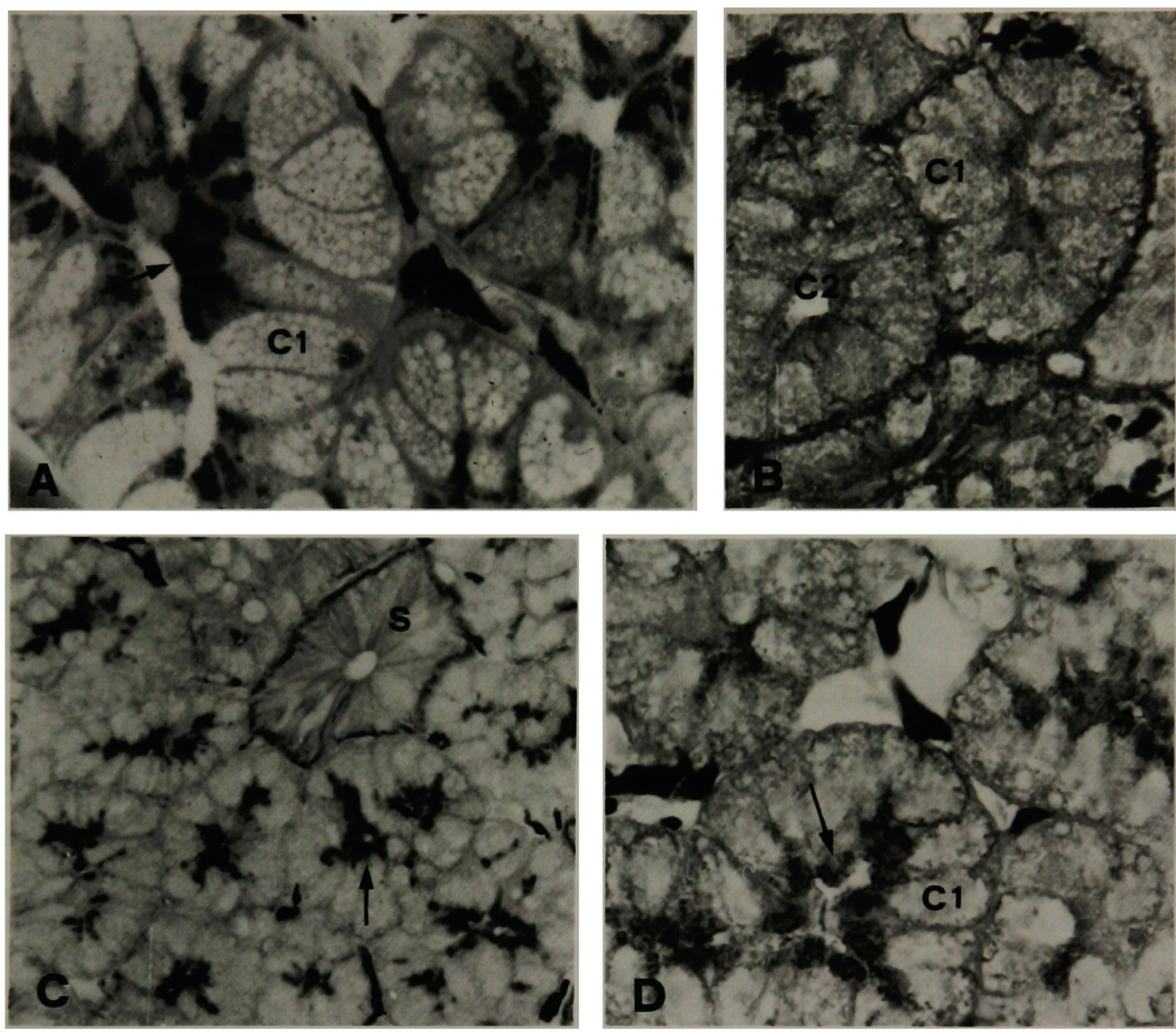

Fig. 1. External nasal gland of the ruin lizard (Podarcis sicula campestris) stained using different histochemical methods. Two well differentiated tracts could be distinguished in the glandular tubules: a proximal tract, consisting of striated cells (S), without any apparent secretory granules, and a distal (blind) tract composed of two different secretory cell types (C1 and C2). A: Periodic acid-Schiff (PAS)-Semithin section. C2 cells (arrow) were intensely stained by the PAS method, while C1 cells were unreactive. $\times 1000$. B: Peanut lectin (PNL) after sialidase digestion. Neuraminidase treatment imparted a weak PNL positivity to the $\mathrm{C} 2 \mathrm{cells}$. $\mathrm{Cl}$ cells were unreactive. $\times 400$. C: Soybean lectin (SBL). A strong reactivity for this lectin was present in C2 cells (arrow). S: striated cells of the proximal tract. Cl cells were unreactive. D: Wheat germ lectin (WGL). A moderate staining was present in C2 cells (arrow). C1 cells were unreactive. $\times 400$.

and $\mathrm{pH} 2.5$ and HID reaction, in particular in the periphery of the granules. In highly magnified semithin sections, the secretory granules frequently showed a PAS positive rim or cap and stained intensely with the silver method (Fig. 2A). A moderate affinity towards SBA was found, particularly in the periphery of the granules. No staining was seen with Con A (Fig. 2B) or WPA (Fig. 2C). Certain binding sites were likewise found with WGA and PNA (Fig. 2D). Digestion with sialidase increased the PNA staining, whereas it did not affect significantly the reactivity with SBA.

The second cell type (C2), included small cells which were compressed between large $\mathrm{C} 1$ cells. They stained intensely with the silver method (Fig. 2A). These cells exhibited an intense PAS reaction and stained with $\mathrm{AB}$ at $\mathrm{pH} 1.0$ and $\mathrm{pH} 2.5$, also after pretreatment with hyaluronidase. The $\mathrm{C} 2$ cells reacted intensely with Con $\mathrm{A}$ (Fig. 2B) and WPA (Fig. 2C). Weak staining was obtained with SBA, WGA and PNA (Fig. 2D). Pretreatment with sialidase moderately increased the binding with PNA.

The intermediate tract consisted of secretory cells intercalated among striated cells (Fig. 2D).

In this tract, C2 cells were enlarged, assumed a prismatic shape and were larger in number. They stained, as in the distal tract, with the PAS procedure, $\mathrm{AB}$ at $\mathrm{pH} 1$ and $\mathrm{pH} 2.5$ and HID staining techniques.

In these cells lectin binding pattern were different from that of the same cells from the blind tract. They stained intensely with PNA (Fig. 2D), whereas they did not react with WPA and Con $A$. The $\mathrm{C} 2$ cells likewise 

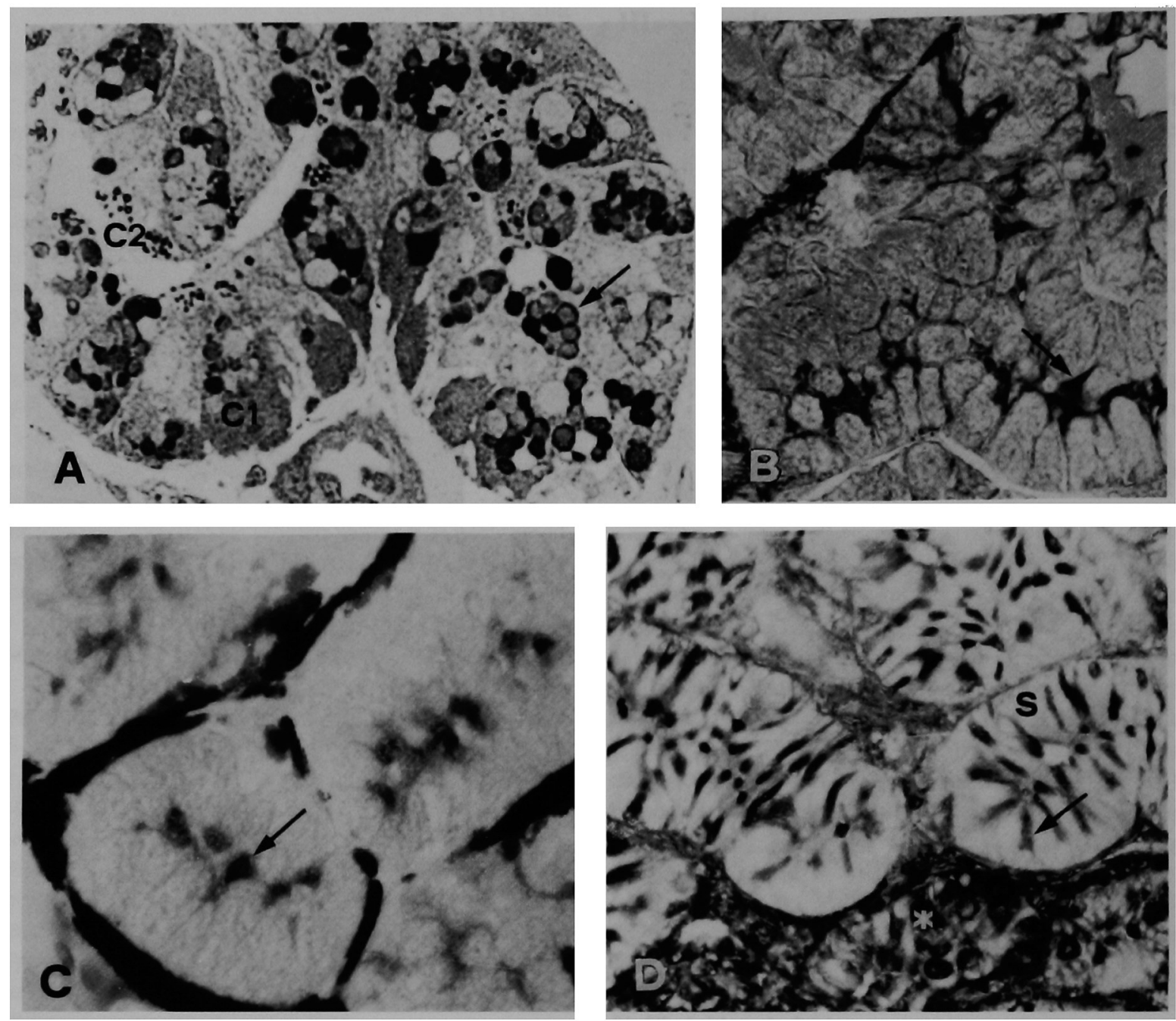

Fig. 2. External nasal gland of the seps (Chalcides chalcides) stained using different histochemical methods. Three different segments could be distinguished in the glandular tubules: the distal, intermediate and proximal tracts. The distal tract was composed of two different secretory cell types ( $\mathrm{C} 1$ and $\mathrm{C} 2)$. The intermediate tract consisted of secretory cells intercalated among striated cells (S). The proximal tracts was composed merely of striated cells. A: Silver method. Semithin section. In the distal tract of the glandular tubules $\mathrm{Cl}$ cells were characterized by large secretory granules with different degree of positivity. C2 cells showed little secretory granules in the apical cytoplasm. The granules of $\mathrm{Cl}$ cells often contained a rim or cap of more intensely stained material (arrow). $\times 1000 . \quad$ B: Concanavalin A (Con A). Staining was evident in $\mathrm{C} 2$ cells (arrows) of the distal tract of the glandular tubules. C1 cells were unreactive. $\times 250$. C: Winged pea lectin (WPL). Only the C2 cells (arrow) of the distal tract of the secretory tubules stained intensely with this lectin. $\times 400$. D: Peanut lectin (PNL). C2 cells (arrow) of distal and, moreover, intermediate tracts stained with this lectin. Binding sites were also found in $\mathrm{Cl}$ cells (*) of the distal tract. S: striated cell in the intermediate tract of glandular tubules. $\times 250$.

displayed moderate affinity towards SBA and, to a lesser extent, towards WGA. Digestion with sialidase did not considerably affect the staining with PNA and SBA.

In the intermediate tract, $\mathrm{Cl}$ cells became progressively less numerous towards the proximal tract. These cells exhibited histochemical features identical to the same cells in the distal tract.

The proximal tract was composed merely of striated cells, which constitute a homogeneous striated segment. These cells did not stain with any of the histochemical methods employed.

In control sections, exposure to $\mathrm{DAB}-\mathrm{H}_{2} \mathrm{O}_{2}$ medium after substitution of PBS for lectin-HRP conjugates produced no specific staining. Lectin staining was significantly inhibited by the addition of the corresponding hapten sugar.

Lectin bindings in the secretory cells of the external nasal gland in ruin lizard and seps were summarized in table 2 .

\section{Discussion}

In the present study the distribution patterns of sugar residues were examined in the secretory cells of the exter- 
Table 2. Lectin binding patterns in secretory cells of the external nasal gland from ruin lizard and seps ${ }^{1,2)}$

\begin{tabular}{lccccccc}
\hline Lectin & \multicolumn{1}{c}{$\begin{array}{c}\text { ruin } \\
\text { distal }\end{array}$} & $\begin{array}{c}\text { lizard } \\
\text { tract }\end{array}$ & \multicolumn{2}{c}{ distal } & tract & intermediate & tract \\
\hline & C1 & C2 & C1 & C2 & C1 & C2 \\
\hline Con A & - & - & - & +++ & - & - \\
WGA & - & ++ & + & + & + & + \\
SBA & - & +++ & ++ & + & ++ & ++ \\
PNA & - & - & + & + & + & +++ \\
WPA & - & - & - & +++ & - & - \\
sialidase-SBL & - & +++ & ++ & + & ++ & ++ \\
sialidase-PNL & - & + & ++ & ++ & ++ & +++ \\
\hline
\end{tabular}

1) $\mathrm{C} 1$ and $\mathrm{C2}$ : secretory cell types.

2) - : negative reaction, + : weak reaction, ++ : moderate reaction, $+++:$ intense reaction.

nal nasal gland of ruin lizard (Podarcis sicula campestris) and seps (Chalcides chalcides).

Two different types of secretory cells were described in the terminal glandular tract of the external nasal gland of the ruin lizard. The first cell type (C1), included PAS negative, not alcianophylic cells, which did not contain histochemically detectable carbohydrates. They are, nearly certainly, serous secreting cells. The second cell type (C2) elaborated a secretory product probably consisting of acidic periodate-reactive glycoproteins with abundant sulfated esters. The results obtained by lectin histochemistry demonstrated the presence of glycosidic residues of $\mathrm{N}$-acetyl-D-glucosamine and, in particular, $\mathrm{N}$-acetylD-galactosamine. Certain terminal sialic acid residues attached to penultimate Gal $\beta 1$, 3GalNAc residues are present as well.

Two secretory cell types could likewise be distinguished in the terminal glandular tract of the external nasal gland of seps. The first cell type (C1) contains a complex secretory product. In the secretory granules, glycoconjugates are frequently concentrated to form a rim or cap. They contain periodate-reactive acidic glycoproteins with an abundance of sulfated esters. Lectin histochemistry reveals the presence of glycosidic residues of $\mathrm{N}$-acetyl-Dgalactosamine, $\beta(1,4) \mathrm{GlcNAc}$ oligomers and $\mathrm{Gal} \beta 1$, 3GalNAc terminal sequences. Penultimate Gal $\beta 1$, 3 GalNAc residues capped by sialic acid in glycoproteins are present as well.

In the intermediate tract of the glandular tubules, these cells exhibited the same histochemical features.

In a previous ultrastructural study on the external nasal gland of this Scincidae, we observed that the granules of the first cell type frequently contained a rim or a cap of electron dense material which, at high magnification, revealed a crystal-like structure [5]. They consisted largely of sulfated glycoproteins and we hypothesized that they may be an expression of a mechanism underlying the packaging of glycoproteins.

The second type of secretory cells (C2) produced main- ly sulfomucins; sialomucins were likewise present in these cells. Lectin histochemistry suggested the presence of abundant terminal L-fucose residues bound to penultimate GlcNAc residues and/or difucosylated oligosaccharides [9]. Numerous mannose and/or glucose residues were present as well. Furthermore, certain $\beta(1,4)$ GlcNAc oligomers, GalNAc oligomers, GalNAc residues and Gal $\beta 1$, 3GalNAc terminal sequences were present as well as Gal $\beta 1$, 3GalNAc-sialic acid terminal sequences.

In the intermediate tract of the glandular tubules there was an apparent change in the distribution of glycosidic residues in the secretory product of $\mathrm{C} 2$ cells, as revealed by the results obtained by lectin histochemistry. In particular, mannose/glucose and L-fucose terminal residues were not present, whereas GalNAc residues and, mostly, Gal 1 1, 3GalNAc terminal sequences increased in amount.

The histological and histochemical features observed in the external nasal gland of the ruin lizard are similar to those described in Lacerta muralis, in which two different secretory cell types, serous (PAS- negative but rich in proteins) and mucoserous (PAS-reactive and containing both proteins and acidic mucins), were described [21].

The histological features observed in the external nasal gland of the seps are similar to those described in several Scincidae [20], in which two categories of classic glandular cells were described in the distal tract of glandular tubules: seromucous $\mathrm{Cl}$ cells and mucoserous C2 cells.

In Agamidae and Varanidae, the secretory tubules are composed exclusively of a single secretory cell type (C1), which is generally seromucous $[20,22]$. Two secretory cell types $(\mathrm{Cl}$ and $\mathrm{C} 2)$ are present in Gekkonidae, both, in general, mucoserous [20].

As far as we know, there have been no reports concerning the distribution of glycosidic residues in secretory cells of the reptilian external nasal gland.

The secretory product of the external nasal gland of reptiles flows into the vestibulum and forms a protective film on its epithelium. The mucus covering the nasal epithelium of vertebrates seems to play an important role in a variety of such functions, as protection from the atmospheric dust, lubrication and defense against the invasion of bacteria and other exogenous macromolecules. In the olfactory area furthermore it appears to perform an active part in chemoreception [9].

The specific function of different glycosidic residues of oligosaccharidic chains in mucous glycoproteins remains to be elaborated. However, most of the properties of mucus depend probably upon its carbohydrate moieties. For example, sialic acid residues contribute to mucus viscosity and ability of bacterial entrapment [19].

\section{References}

1. Biagini, G., Borsetti, P. and Laschi, R.: Two rapid stainings for mucopolysaccharides and collagen in semi-thin sections. $J$. Submicrosc. Cytol. 4; 283-285, 1972. 
2. Bonucci, E.: Manuale di Istochimica, Lombardo, Roma, 1981, pp. 151-152.

3. Danguy, A.: Perspective in modern glycohistochemistry. Eur. J. Histochem. 39; 5-14, 1995.

4. Dunson, W. A.: Salt gland in Reptiles. In "Biology of the Reptilia", Vol. 5, ed. by C. Gans and W.R. Dawson, Academic Press, N.Y., 1976, pp. 413-445.

5. Ferri, D. and Liquori, G. E.: The external nasal gland in Chalcides chalcides (Reptilia, Scincidae): substructure and carbohydrate cytochemistry of secretory granules. Atti Soc. Peloritana Sc. 31; 77-87, 1985-87.

6. Ferri, D. and Liquori, G. E.: Characterization of secretory cell glycoconjugates in the alimentary tract of the ruin lizard (Podarcis sicula campestris De Betta) by means of lectin histochemistry. Acta Histochem. (Jena) 93; 341-349, 1992.

7. Gabe, M. et St. Girons, H.: Polymorphisme des glandes nasales externes des Sauriens. C.R. Acad. Sc. Paris 272; 12751278,1971

8. Gabe, M. et St. Girons, H.: Contribution à la morphologie comparée des fosses nasales et de leur annexes chez les Lépidosauriens. Mem. Mus. Nat. Hist. Nat. Paris A98; 1-87, 1976.

9. Getchell, T. V. and Getchell, M. L.: Regulatory factors in the vertebrate olfactory mucosa. Chem. Senses 15; 223-231, 1990.

10. Goldstain, I. J. and Poretz, R. D.: Isolation, physiochemical characterization, and carbohydrate-binding specificity of lectins. In "The Lectins. Properties, Functions, and Applications in Biology and Medicine", ed. by I. E. Liener, N. Sharon and I. J. Goldstein, Academic Press, London, 1986, pp. 35347.

11. Graham, R. C. and Karnowsky, M. J.: The early stages of absorption of injected horseradish peroxidase in the proximal tubules of mouse kidney: ultrastructural cytochemistry by a new technique. J. Histochem. Cytochem. 14; 291-302, 1966.

12. Kobata, A.: Structures and functions of the sugar chains of glycoproteins. Eur. J. Biochem. 209; 483-501, 1992.

13. Lane, B. P. and Europa, D. L.: Differential staining of ultrathin sections of Epon-embedded tissues for light microscopy. J. Histochem. Cytochem. 13; 579, 1965.

14. Leathern, A. J.C. and Atkins, N. J.: Lectin binding to paraffin section techniques. In "Immunocytochemistry", Academic Press, London - New York, 1983, pp. 39-60.
15. Lev, R. and Spicer, S. S.: Specific staining of sulfated groups with alcian blue at low pH. J. Histochem. Cytochem. 5; 445458, 1964.

16. Lis, H. and Sharon, N.: Protein glycosilation. Structural and functional aspects. Eur. J. Biochem. 2; 1-27, 1993.

17. Mowry, R. and Winkler, C. H.: The coloration of acidic carbohydrates of bacteria and fungi in tissue sections with special reference to capsules of Cryptococcus neoformans, Pneumococci and Staphilococci. Amer. J. Path. 32; 628-629, 1956.

18. Parsons, T.S.: The nose and Jacobson's organ. In "Biology of the Reptilia", Vol. 2, ed. by C. Gans and T. S. Parsons, Acad. Press, London \& New York, 1970, pp. 99-191.

19. Ramphal, R. and Pyle, M.: Evidence for mucins and sialic acid as receptors for Pseudomonas aeruginosa in the lower respiratory tract. Infect. Immunol. 41; 339-344, 1983.

20. Saint Girons, H. and Bradshaw, S. D.: Aspects of variation in histology and cytology of the external nasal gland of Australian lizards. J. Royal Soc. West. Austr. 69; 117-121, 1987.

21. Saint Girons, H. et Joly, J.: Histologie et ultrastructure de la glande nasale externe du Lacertilien Lacerta muralis et de l'Amphisbénien Trogonophis wiegmanni (Reptilia, Lacertidae et Trogonophidae). Arch. Biol. (Bruxelles) 86; 97-126, 1975.

22. Saint Girons, H., Rice, G. E. and Bradshaw, S. D.: Histologie comparée et ultrastructure de la glande nasale externe de quelques Varanidae (Reptilia: Lacertilia). Ann. Sci. Nat. Zool. Paris 3; 15-21, 1981.

23. Schmidt Nielsen, $K$. and Fange, R.: Salt gland in marine reptiles. Nature Lond. 182; 783-785, 1958.

24. Spicer, S. S.: Diamine methods for differentiating mucosubstances histochemically. J. Histochem. Cytochem. 13; 211234, 1965.

25. Spicer, S.S. and Schulte, B. A.: Diversity of cell glycoconjugates shown histochemically: a perspective. J. Histochem. Cytochem. 40; 1-38, 1992.

26. Ueda, T., Mittal, A. K., Fujimori, O. and Yamada, K.: The utility of HID-AB pH 2.5-PAS and HID-PAS methods for cytochemical analysis of mucosubstances secreted by fish epidermis. Acta Histochem. Cytochem. 27; 613-617, 1994.

27. Zanetta, J. P., Badache, A., Maschke, S., Marschal, P. and Kuchler, S.: Carbohydrates and soluble lectins in the regulation of cell adhesion and proliferation. Histol. Histopath. 90; 385-412, 1994. 